\title{
MIR137 Gene
}

National Cancer Institute

\section{Source}

National Cancer Institute. MIR137 Gene. NCI Thesaurus. Code C81737.

This gene is involved in the regulation of gene expression and plays a role in the development of glioblastoma multiforme, non-small cell lung and squamous cell carcinomas. 